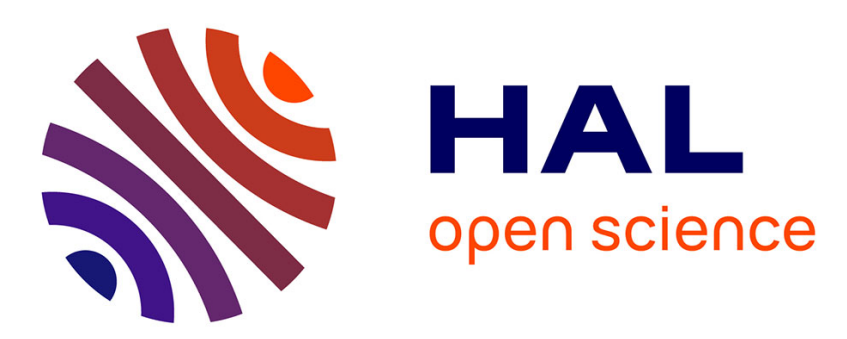

\title{
Some adult and larval nematodes from fishes off New Caledonia
}

\author{
Shokoofeh Shamsi, Anita Poupa, Jean-Lou Justine
}

\section{To cite this version:}

Shokoofeh Shamsi, Anita Poupa, Jean-Lou Justine. Some adult and larval nematodes from fishes off New Caledonia. Parasitology Research, 2020, 119, pp.2473-2484. 10.1007/s00436-020-06755-8 . hal-02879295

\section{HAL Id: hal-02879295 \\ https://hal.science/hal-02879295}

Submitted on 23 Jun 2020

HAL is a multi-disciplinary open access archive for the deposit and dissemination of scientific research documents, whether they are published or not. The documents may come from teaching and research institutions in France or abroad, or from public or private research centers.
L'archive ouverte pluridisciplinaire HAL, est destinée au dépôt et à la diffusion de documents scientifiques de niveau recherche, publiés ou non, émanant des établissements d'enseignement et de recherche français ou étrangers, des laboratoires publics ou privés. 


\section{Some adult and larval nematodes from fishes off}

\section{New Caledonia}

Shokoofeh Shamsi*1, Anita Poupa ${ }^{1}$, Jean-Lou Justine ${ }^{2}$

1- School of Animal and Veterinary Sciences, Graham Centre for Agricultural Innovation, Charles Sturt University, Australia

2- ISYEB, Institut de Systématique, Évolution, Biodiversité (UMR7205 CNRS, EPHE, MNHN, UPMC), Muséum National d'Histoire Naturelle, CP 51, 55 rue Buffon, 75231 Paris cedex 05, France

*corresponding author's email: sshamsi@csu.edu.au

\section{Published in:}

Parasitology Research, 2020

doi: https://doi.org/10.1007/s00436-020-06755-8 


\section{ABSTRACT}

A collection of nematodes from the Muséum National d'Histoire Naturelle (National Museum of Natural History), Paris, France was studied. The nematodes had previously been collected from a range of marine fish hosts. The aim of this study was to investigate the identity of these nematodes. Detailed body measurements of the nematodes were taken via light microscopy and where possible first and second internal transcribed spacers (ITS-1 and ITS-2) of ribosomal DNA were subjected to PCR, purified and sequenced. Six species and three larval types were found from a range of fish species and included 13 new host records and two new geographical records. Of the taxa found, Hysterothylacium kajikiae is the only species which may have zoonotic potential. The majority of host fish in this study are edible species, commercially and recreationally fished and frequently incorporated into the cuisine of New Caledonia as raw fish dishes. This study will allow better understanding of the diversity, life cycles, distribution and host-parasite relationships in the New Caledonia area.

Keywords: New Caledonia; Nematoda; Parasites; Ascaridoids; Seafood safety; Aquatic Animal Health; Environment 


\section{Introduction}

A large number of studies have described the diversity of parasites in marine fishes from New Caledonia (Justine 2010) and cover a broad range of parasitic phyla. However, these studies have rarely focused primarily on nematodes which are considered to be of high zoonotic importance. The larval form of nematodes are difficult to accurately identify from morphology alone (Justine et al. 2010a; Justine et al. 2010b; Justine et al. 2012a) and molecular studies are thus required, particularly for zoonotic marine ascaridoids (Shamsi et al. 2015; Shamsi et al. 2017; Shamsi et al. 2018a). A more comprehensive understanding of host-parasite interactions is necessary to determine the overall and potential impact marine nematodes may have on wildlife and human health. This is particularly important due to high consumption of fish/seafood in this area and the potential risk associated with a culinary preference for raw fish dishes. Information about these parasites from New Caledonia remains incomplete and new species and parasites are still being described (Moravec and Justine 2018a; Moravec and Justine 2018b; Moravec and Justine 2019a; Moravec and Justine 2019b; 2020a,b). The aim of the present study was to identify adult and larval nematode parasites from marine fish in New Caledonia.

\section{Materials and methods}

\section{Hosts}

Nematodes were collected from a variety of marine fish hosts from New Caledonian waters during 2003-2011. by one of us (JLJ) with the help of his students and sometimes visiting colleagues in the years 2003-2011. The nematodes were collected from many species of marine fish hosts from New Caledonian waters and are deposited now in the collections of the Muséum National d'Histoire Naturelle in Paris, France (MNHN). Most fish specimens were from the vicinity of Nouméa, New Caledonia and were collected by various means (fishing and 
purchasing from the fishmarket of Nouméa); however, Kajikia audax, a pelagic fish, was caught far off the coast. Host morphological identification was performed by available keys and sometimes confirmed by ichthyologists. In rare instances, precise identification of fish hosts was problematic as these fish did not perfectly match descriptions of existing species and therefore have only been identified to the genus level.

\section{Parasite collection}

Parasites (larvae and adults) were collected via a variation of the wash method (Justine et al. 2012b) from the abdominal cavities of the fish. Most were found in the stomach and intestinal lumen but some were found in encapsulations on surfaces of the abdominal organs. In this case, were removed with fine tissue forceps. Specimens were washed in saline and fixed in $70 \%$ ethanol.

\section{Morphology}

A small cross-section of the mid-body from each parasite was excised and frozen until subsequent molecular studies. The anterior and posterior ends were then mounted on microscope slides and cleared in lactophenol for morphological examination. For larger, thicker worms, the anterior and posterior ends were soaked in Berland's fluid for 48 hours prior to being mounted for additional clearing. Specimens were assigned into distinct groups based on the morphology of lips (labia), tail, reproductive, digestive and excretory systems. A number of representatives from each group were selected for detailed measurement of important morphological features. A drawing of each parasite was made using a microscope equipped with a drawing tube.

\section{Molecular study}

For the groups that were subject to molecular study, one representative from each parasite group per host species was selected for molecular examination. Genomic DNA (gDNA) was isolated 
from each individual specimen via sodium dodecyl-sulphate/proteinase K treatment, columnpurified (Wizard ${ }^{\mathrm{TM}}$ DNA Clean-Up, Promega, Wisconsin, USA) and eluted into $45 \mu 1$ of water. PCR was used to amplify the ITS-1 and ITS-2 regions using previously used primer sets (Ghadam et al. 2018). Cycling conditions: initial $94^{\circ} \mathrm{C} / 5^{\prime}$, then $94^{\circ} \mathrm{C} / 30$ ", $55^{\circ} \mathrm{C} / 40^{\prime \prime}, 72^{\circ} \mathrm{C} / 40^{\prime \prime}$ $\times 30$ cycles, $72{ }^{\circ} \mathrm{C} / 5^{\prime}$ extension and $4{ }^{\circ} \mathrm{C}$. A $4 \mu$ aliquot of each amplicon was examined on a $1.5 \% \mathrm{w} / \mathrm{v}$ agarose gel. Amplicons were purified over mini-columns (Wizard ${ }^{\mathrm{TM}}$ PCR Prep, Promega, WI, USA), eluted in $35 \mu 1 \mathrm{H}_{2} \mathrm{O}$ and then subjected to automated sequencing using the same primers as for PCR. Sequences were aligned using the computer programme ClustalX and then adjusted manually. Polymorphic sites were designated using International Union of Pure and Applied Chemistry (IUPAC).

\section{Results}

Table 1 summarises the parasite taxa found in each host in the present study. Results are given only for the specimens measured and sequenced. For the following results sections, all measurements are in millimetres unless otherwise stated. Mean measurements are given followed by range and number of specimens measured in parentheses. Some features were not measurable due to poor quality or incompleteness, therefore number of features measured may not always match number of specimens for that taxon. As mentioned previously, 10 representatives from each group were selected for measurement. If in the case some features were not determinable, additional specimens may have been measured to compensate for this.

\section{Adult Nematoda}

\section{Hysterothylacium kajikiae Shamsi, 2017}

Origin of specimens: The nematodes were collected during a general survey of the diet of pelagic fish undertaken by the Pacific Community (CPS) in Nouméa. Numerous nematodes were collected from frozen fish stomach/s. Precise information on the catch was: CPS number: 
CHS0307-57; date 18-08-2003; coordinates: $22^{\circ} 26.952 \mathrm{~S}, 165^{\circ} 11.162 \mathrm{E}$, i.e. ca. $120 \mathrm{~km}$ West off New Caledonia). Material communicated by Valérie Allain, CPS, Nouméa. The nematodes were collected by Ian Beveridge.

Males: n=6; from Kajikia audax (Philippi); Accession number: MNHN JNC1402; Specimen numbers: $243-2,243-4,243-6,243-9,244-1$ and 244-5.

Description (Figure 1 a to d): Males body length 39.02 (24.98-52.75; $\mathrm{n}=6)$. Maximum body width $0.65(0.5-0.83 ; \mathrm{n}=6)$. Cuticle lightly annulated, with numerous parallel cuticular ornamentations on ventral surface near posterior end. Three protruding labia with deep postlabial grooves and prominent lateral flanges. Dorsal lip with two double papillae, ventrolateral lips both with a lateral amphid, a single papilla and a double papilla. Height of lips $0.1(0.09-0.12 ; \mathrm{n}=5)$, width $0.09(0.06-0.13 ; \mathrm{n}=5)$. Interlabia well developed. Nerve ring 0.54 $(0.5-0.61 ; n=6)$ from anterior end. Excretory pore just posterior to nerve ring position. Lateral alae absent. Cervical papillae present, around location of nerve ring. Muscular oesophagus, 5.03 (3.3-6.7; $n=6)$ long, slightly broader at posterior end, $12.9 \%(8.5-17.2 \% ; n=6)$ of total body length, ending in glandular ventriculus. Ventriculus subglobular, $0.23(0.13-0.34 ; n=6)$ long. Ventricular appendix length $3.34(1.63-4.75 ; n=5)$. Intestinal caecum length 4.36 (2.28-6.1; $\mathrm{n}=6$ ). Ratio of intestinal caecum to ventricular appendix 1:0.77. Spicules subequal and alate, $3.7(2.47-6.55, \mathrm{n}=6)$ and $3.7(2.5-6.0, \mathrm{n}=6)$ long and $11 \%(6-23 \%)$ and $11 \%(6-20 \%)$ of body length. Tail conical, relatively short and aspinose. Caudal papillae small and 21 pairs in total, 16 pairs precloacal, one pair of double paracloacal and 4 post cloacal pairs. Cloaca $0.22(0.19$ $0.28 ; \mathrm{n}=6$ ) from posterior end.

Females: $\mathrm{n}=8$; from Kajikia audax (Philippi); Accession number: MNHN JNC1402, MNHN JNC1403; Specimen numbers: 243-3, 243-5, 243-7, 243-8, 244-2, 244-3, 244-4 and 244-6.

Description (Figure 1c \& d): Body length 63.73 (21.58-87.95; n=7). Maximum body width $1.11(0.78-1.3 ; \mathrm{n}=8)$. Cuticle finely annulated. Labia height $0.12(0.06-0.23 ; \mathrm{n}=8)$, width 0.12 
$(0.08-0.15 ; \mathrm{n}=8)$. Lips/papillae/amphids as per male. Nerve ring $0.6(0.33-0.76 ; \mathrm{n}=6)$ from anterior end. Lateral alae absent. Excretory pore not observed. Muscular oesophagus, length $5.7(2.65-7.9 ; n=8)$, slightly broader at posterior end, $8.94 \%(4.16-12.4 \% ; n=8)$ of total body length, ending in glandular ventriculus. Ventriculus subglobular, length $0.25(0.1-0.39 ; n=8)$, $0.39 \%(0.16-0.61 \% ; n=8)$ of total body length. Ventricular appendix length 5.63 (4.3-7.23; $\mathrm{n}=3)$. Intestinal caecum length $8.21(5.35-14.7 ; n=5)$. Ratio of intestinal caecum to ventricular appendix 1:0.69 (8.21:5.63). Vulva located $19.25(7.93-29.45 ; n=3)$ from anterior end. Eggs oval-shaped, length $0.1(0.07-0.16 ; n=5)$, width $0.07(0.06-0.08 ; n=5)$. Tail conical, aspinose and relatively long. Anus located $0.87(0.45-1.13 ; n=7)$ from posterior end. No caudal papillae. Genetic characterisation: Sequences of the ITS-1 and ITS-2 were obtained separately for one male 243-1 and one female 243-3. ITS-1 was 429 bp and identical among specimens (GenBank accession numbers: MT428328-9). ITS-2 was 271 bp and identical among specimens (GenBank accession numbers: MT428344-5).

\section{Raphidascaris sp.}

Immature females: $\mathrm{n}=5$; from Lutjanus sp. Bloch; Accession number: MNHN JNC3369; Specimen numbers: 245-5, 245-6, 245-7, 245-8, 245-9 and 245-10.

Description (Figure 1 e \& f): All five specimens were immature females. Body length 3.82 (3.18-4.18; $\mathrm{n}=5)$. Maximum body width $0.27(0.22-0.36 ; \mathrm{n}=5)$. Cuticle lightly annulated transversely. 3 protruding labia, height $0.03(0.03-0.04 ; n=5)$, width $0.05(0.05-0.05 ; n=5)$. Anterior lateral alae present. Nerve ring $0.16(0.11-0.2 ; n=5)$ from anterior end. Muscular oesophagus, more expanded at distal end, $0.5(0.43-0.57$; $=5)$ long, 13.09\% $(11.26-14.92 \%$; $\mathrm{n}=5$ ) of total body length, ending in glandular ventriculus. Ventriculus transversely oval, 0.05 $(0.04-0.05 ; \mathrm{n}=5)$ long, $1.31 \%(1.05-1.31 \% ; \mathrm{n}=5)$ of total body length. Ventricular appendix 0.36 $(0.25-0.54 ; \mathrm{n}=4)$ long. Vulva located $1.13(1.1-1.15 ; \mathrm{n}=2)$ from anterior end. Eggs absent. Tail conical with multispinous tip. Anus $0.19(0.15-0.21 ; n=5)$ from posterior end. 
Adult female: $\mathrm{n}=1$; from Nemipterus furcosus (Valenciennes); Accession number: MNHN JNC214D; Specimen number 212-1.

Description (Figure 1g \& h): Gravid female. Body length 8.68. Maximum body width 0.49. Cuticle finely annulated. 3 protruding labia, height 0.05 , width 0.05 . Anterior lateral alae present. Nerve ring 0.25 from anterior end. Muscular oesophagus, slightly more expanded at caudal end, ending in glandular ventriculus. Oesophagus length $1.05,12.1 \%$ of total body length. Ventriculus transversely oval, 0.06 in length, $0.69 \%$ of total body length. Ventricular appendix 0.39 long. Vulva 1.83 from anterior end. Egg length 0.04 and egg width 0.03 . Tail with multispinous tip. Anus 0.33 from posterior end.

Adult male: $\mathrm{n}=1$; from Nemipterus furcosus (Valenciennes); Accession number: MNHN JNC214D; Specimen number: 212-2. This specimen was not in good morphological condition to be described.

Genetic characterisation: Eight specimens including 245-5, 245-6, 245-7, 245-8, 245-9, $245-$ 10, 212-1, 212-2 were sequenced for ITS-1. The ITS-1 was $468 \mathrm{bp}$ and 100\% identical among specimens (GenBank accession numbers: MT428337-43). The ITS-2 sequences were obtained for seven specimens $(245-5,245-6,245-7,245-8,245-9,245-10$ 212-1 and 212-2) (GenBank accession numbers: MT428354-61). They were 100\% identical among specimens and $287 \mathrm{bp}$ long. An identification as $R$. lophii was made based on the identical sequence available in the GenBank (Table 1).

\section{Cucullanus sp.}

Adult female: $\mathrm{n}=1$; from Epinephelus cyanopodus (Richardson); Accession number: MNHN JNC1888; Specimen number: 282-3.

Description (Figure 1 i \& j): Gravid, medium sized with whitish body. Total body length 6.9. Maximum body width 0.32 . Cuticle covered in fine, closely situated annulations. Lateral alae absent. Nerve ring 0.43 from anterior end, surrounding oesophagus at narrowest point. 
Excretory pore not observed. Head rounded, somewhat asymmetrical in lateral view. Oral aperture dorsoventrally elongate, surrounded by raised narrow membranous ala (collarette) supported by a row of minute basal teeth. Four submedian cephalic papillae (two pairs) and one pair of lateral amphids present. No marginal oral papillae. One pair of deirids small and hooked, situated just posterior to level of eosophago-intestinal junction, 1.32 from anterior end. Oesophagus muscular and double club-shaped, width 0.09 at narrowest point and width 0.22 at widest points. Oesophagus expansion at anterior end forming a large elongate pseudobuccal capsule (oesophastome). Expansion at posterior end of oesophagus roughly same width as pseudobuccal capsule. Oesophagus length 1.1, 15.94\% of total body length. Oesophagus opens to intestine through a large valve. Oesophageal-intestinal valve 0.05 long, extending into lumen of anterior intestine. Vulva slightly elevated, located $2 \mathrm{~mm}$ from posterior end (could not be measured from anterior end due to cross section taken). Vagina directed anteriorly, weakly muscular. Uteri opposed. Eggs oval shaped, 0.06 long (0.04-0.7; $n=7), 0.04$ wide (0.04-0.05; $\mathrm{n}=7$ ). Tail conical and aspinose but with pointed tip, one pair of caudal phasmids near mid length of tail. Anus 0.25 from posterior end.

Genetic characterisation: No molecular work was completed on this specimen due to preservation method.

\section{Procamallanus (Spirocamallanus) monotaxis (Olsen 1952)}

Males: $\mathrm{n}=5$; from Lethrinus genivittatus (Valenciennes); Accession number: MNHN JNC221B; Specimens numbers: 200-2, 200-7, 200-8, 200-9 and 200-12.

Description (Figure $1 \mathrm{k} \&$ 1): Total body length $9.81(9.6-10.2 ; n=4)$. Body width 0.25 (0.22$0.28 ; \mathrm{n}=5)$. Cuticle covered in fine transverse annulations. Nerve ring $0.26(0.25-0.28 ; n=4)$ from anterior end, wrapped around junction of muscular oesophagus and glandular oesophagus. Excretory pore $0.4(0.39-0.43 ; n=4)$ from anterior end. Deirids small and simple, $0.18(0.12-$ $0.19, \mathrm{n}=3$ ) from anterior end. Mouth aperture oval to square provided with narrow circumoral 
flange and surrounded by six flat, crescent-shaped elevations and 12 submedian cephalic papillae arranged in three circles, each formed by four papillae; papillae of external circle distinctly larger. One pair of small lateral amphids present. Large orange-brown buccal capsule with smooth spiral grooves, some of which incomplete. Length of buccal capsule including basal ring $0.09(0.09-0.09 ; n=4)$. Maximum width of buccal capsule $0.07(0.06-0.07 ; n=4)$. Muscular oesophagus length $0.18(0.16-0.19 ; n=4)$. Glandular oesophagus length $0.22(0.2-$ $0.24 ; n=4)$. No caeca or diverticula. Caudal alae present. Three pairs of equally spaced preanal pedunculate papillae. Postanal papillae: 4 pairs of anterior subventral and 2 pairs of posterior lateral pedunculate papillae; additional 2 pairs of small transversely elongate sessile papillae surrounding cloacal opening. Spicules unequal, longer and more sclerotised right spicule length $0.3(0.29-0.33 ; n=5)$, left spicule length $0.21(0.17-0.28 ; n=5)$. Both spicules with pointed tips. Females: $\mathrm{n}=5$; from Lethrinus genivittatus (Valenciennes); Accession number: MNHN JNC221B; Specimens numbers: 200-1, 200-3, 200-4, 200-5 and 228-1

Description (Figure $1 \mathrm{~m} \& \mathrm{n})$ : Total body length 13.8 (12.7-15.95; n=3). Body width 0.47 $(0.44-0.51 ; n=5)$. Cuticle covered in fine transverse annulations. Nerve ring 0.27 (0.25-0.29; $\mathrm{n}=4$ ) from anterior end, wrapped around junction of muscular oesophagus and glandular oesophagus. Excretory pore $0.38(0.32-0.5 ; n=3)$ from anterior end. Deirids slightly unequal, located $0.18(0.17-0.19 ; n=4)$ to $0.2(0.19-0.21 ; n=4)$ from anterior end. Buccal capsule and oral aperture same as male. Length of buccal capsule including basal ring $0.1(0.1-0.1 ; n=4)$. Muscular oesophagus length $0.19(0.19-0.21 ; n=4)$. Glandular oesophagus length $0.3(0.28$ $0.33 ; \mathrm{n}=4)$. No caeca or diverticula. Numerous larvae in uterus. Vulval lips not elevated. Muscular vagina directed posteriorly. Tail rounded with a digit-like projection with two (dorsal and ventral) terminal cuticular spikes on tip. Anus $0.12(0.1-0.16 ; n=4)$ from posterior end.

Genetic characterisation: No molecular work was completed on this specimen due to preservation method. 


\section{Camallanus carangis Olsen, 1954}

Male: n=1; from Parupeneus heptacanthus (Lacepède); Accession number: MNHN JNC364E; Specimen number: 231-19

Description (Figure 1 o \& p): Total body length 6.3. Maximum body width 0.22 . Body cuticle with fine transverse annulations. Nerve ring 0.24 from anterior end, located just posterior to tips of tridents. One pair of deirids both 0.4 from anterior end. Excretory pore 0.39 from anterior end. Buccal capsule large and orange-brown in colour with smooth longitudinal ridges, some incomplete. Length of buccal capsule including basal ring 0.15 , maximum width of buccal capsule 0.15 . Mouth aperture slit-shaped, surrounded by four submedian cephalic papillae and two lateral amphids. Length of tridents between 0.12 and 0.15 . Muscular oesophagus 0.69 in length. Glandular oesophagus 0.63 in length. Ratio of muscular oesophagus to glandular oesophagus $0.69: 0.63=1: 0.91$. Buccal capsule and oesophagi representing $23.25 \%$ of total body length. No caeca or diverticula. Posterior part of body with caudal alae. Spicules unequal, right (longer) spicule length 0.33 (appears bent dorsally at point of anus as result of physical manipulation, not a taxonomic feature), left shorter and less sclerotized, spicule length 0.15 . Length ratio of spicules 0.33:0.15 $=1: 0.45$. Two pairs of sessile paracloacal papillae. Seven pairs preanal and six pairs of postanal pedunculate papillae. Anus 0.1 from posterior end.

Genetic characterisation: No molecular work was completed on this specimen due to preservation method.

\section{Nematode larvae:}

\section{Hysterothylacium larval type VI of Shamsi et al. 2013}

Materials examined: 14 specimens from Saurida undosquamis (Richardson) (Accession number: MNHN JNC570B; Specimen number: 196-6), Cheilinus fasciatus Bloch (Accession number: MNHN JNC129C; Specimen number: 204-1), Nemipterus furcosus (Valenciennes) 
(Accession number: MNHN JNC250A\&B, JNC260H and JNC259G; Specimen number: 21617, 216-25, 221-11, 222-6), Parupeneus heptacanthus (Lacepède) (Accession number: MNHN JNC364E; Specimen number: 231-17, 231-23), Chaetodon auriga Forsskål (Accession number: MNHN JNC384A; Specimen number: 234-5), Moolgarda seheli (Forsskål) (Accession number: MNHN JNC3359; Specimen number: 246-1, 246-4), Gymnocranius grandoculis (Valenciennes) (Accession number: MNHN JNC1726; Specimen number: 280-1, 280-4 and 280-7).

Description (Figure 2 a \& b): Third stage larvae (Figure 2 i\&j). Total body length 5.63 (3.139.68; $\mathrm{n}=14)$, maximum body width $0.18(0.08-0.28 ; \mathrm{n}=14)$. Boring tooth absent. Labia poorly developed. Nerve ring $0.23(0.12-0.38 ; n=13)$ from anterior end. Excretory pore located between nerve ring and tip of intestinal caecum, closer to intestinal caecum, $0.4(0.34-0.46$; $\mathrm{n}=2)$ from anterior end. Oesophagus muscular, length $0.52(0.35-0.79 ; n=13), 9.24 \%(6.22$ $14.03 \% ; n=13$ ) of total body length, ending in glandular ventriculus. Ventriculus subglobular, length $0.08(0.04-0.18 ; n=13), 1.42 \%(0.71-3.2 \% ; n=13)$ of total body length. Ventricular appendix $0.48(0.16-0.85 ; \mathrm{n}=11)$ long. Intestinal caecum length $0.22(0.1-0.45 ; \mathrm{n}=12)$. Ratio of intestinal caecum to ventricular appendix $0.22: 0.48=1: 2.18$. Tail conical, slightly swollen at tip, decorated with a single minute spine. Anus $0.19(0.11-0.25 ; \mathrm{n}=14)$ from posterior end.

\section{Genetic characterisation:}

ITS-2 was obtained for one specimen (280-1) from Gymnocranius grandoculis (Valenciennes). It was 262 bp (GenBank accession number: MT428346). Attempts to obtain sequences from the remaining specimens was not successful. There was no identical comparable sequence from adult specimens available in the GenBank to allow specific identification.

\section{Hysterothylacium larval type XIV of Shamsi et al. 2015}

Materials examined: 14 specimens from Saurida undosquamis (Richardson) (Accession numbers: MNHN JNC570B, JNC571B, JNC502C; Specimen number: 196-1, 196-3, 196-10, 
197-2, 197-4, 197-5, 219-19) and Nemipterus furcosus (Valenciennes) (Accession numbers: MNHN JNC254D, JNC379C; Specimen numbers: 233-3, 233-7, 233-9, 239-6, 239-7, 239-9 and 239-10).

Description (Figure 2 b \& c): Third stage larvae (Figure k \& i). Body length 4.85 (2.4-7.35; $\mathrm{n}=14)$. Maximum body width $0.17(0.13-0.2 ; \mathrm{n}=13)$. Labia poorly developed. Boring tooth absent. Nerve ring $0.25(0.09-0.36 ; n=11)$ from anterior end. Excretory pore $0.3(0.22-0.36$; $n=3$ ) from anterior end, located between tip of intestinal caecum and nerve ring (closer to nerve ring). Oesophagus muscular, length $0.66(0.5-1.07 ; n=10), 13.61 \%(10.31-22.06 \% ; n=10)$ of total body length, ending in glandular ventriculus. Ventriculus subglobular, length 0.06 (0.06$0.07 ; n=8), 1.24 \%(1.24-1.44 \% ; n=8)$ of total body length. Ventricular appendix length 0.47 $(0.23-0.58 ; n=8)$. Intestinal caecum length $0.18(0.11-0.34 ; n=11)$. Ratio of intestinal caecum to ventricular appendix $0.18: 0.47=1: 2.61$. Tail conical, with tip bent dorsally and decorated with 3-4 minute triangular spines. Anus $0.15(0.12-0.2 ; n=14)$ from posterior end.

Genetic characterisation: Seven specimens 216-8, 197-2, 197-4, 197-5, 197-8, 256-6 and 1979 were subjected to sequencing. ITS- 1 was $436 \mathrm{bp}$ and identical among all specimens (GenBank accession numbers: MT428330-6). ITS2 was 276 bp long (GenBank accession numbers: MT428347-53) and identical among all specimens as well. This larval type was identified as Hysterothylacium persicum based on the identical ITS sequence available in the GenBank (Table 1).

\section{Raphidascaris larval type}

Materials examined: 5 specimens from Saurida undosquamis (Richardson) (Accession number: MNHN JNC570B, JNC571B; Specimen numbers: 196-5, 196-9, 197-3, 197-6) and Parupeneus heptacanthus (Lacepède) (Accession number: MNHN JNC345B; Specimen number: 229-2). 
Description (Figure 2 e \& f): Third stage larvae. Body length 3.4 (2.58-4.68; n=5). Maximum body width $0.18(0.16-0.2 ; n=5)$. Cuticle lightly annulated. Labia poorly developed. Boring tooth present. Excretory pore not observed. Nerve ring $0.19(0.15-0.25 ; n=5)$ from anterior end. Muscular oesophagus, significantly more expanded at distal end, length $0.51(0.47-0.6 ; n=5)$, $15 \%(13.82-17.65 \% ; n=5)$ of total body length. Oesophagus ending in transversely oval, glandular ventriculus. Ventriculus $0.04(0.03-0.06 ; n=5)$ long, $1.18 \%(0.9-1.76 \% ; n=5)$ of total body length. Ventricular appendix $0.27(\mathrm{n}=5)$ long. Tail conical and aspinose with finely pointed tip. Anus $0.13(0.09-0.17 ; \mathrm{n}=5)$ from posterior end (Figure 2f).

Genetic characterisation: ITS-1 and ITS-2 sequences were obtained for one specimen from this group (197-6). The length of the ITS-1 and ITS-2 was 468 and 287 bp (GenBank accession number: MT428360). They were identical with those of mature and immature female Raphidascaris found in the present study and similarly were identified as $R$. lophii.

\section{Discussion}

Despite the high number of studies on parasitic nematodes in New Caledonian fish, it is remarkable that new species (Moravec and Justine 2020a) and new occurrences (present study) still occur. The Nematoda found in the present study were in adult and larval stages and due to the preservation conditions, performing molecular work on all of them was not possible.

Among the adult nematodes found in the present study, the anisakid H. kajikiae is reported for the first time in New Caledonian waters. The parasite was previously reported as a new species from the same host in Australian waters (Shamsi 2017) and based on the description of one male specimen. The present study provided opportunity for examination of more male specimens. Shamsi (2017) considered spicule morphology and size as one of the most distinguishing characteristics for the new species. In the present study, the original description was confirmed, however, spicules were shorter in the smaller (presumably younger) specimens. 
The specimens in the present study had identical ITS-1 and ITS-2 sequences with H. kajikiae reported in Australian waters (Table 1).

This study also provided opportunity to examine and describe a number of adult Raphidascaris specimens. There was no male specimen in good morphological condition in the collection to allow for specific identification. However, ITS sequences of the specimens in the present study collected from the three different host species were identical among specimens suggesting all belong to the same species. A Blast search in GenBank resulted in identical sequence assigned to $R$. lophii in an unpublished study from China (Table 1). In addition, there were a number of other sequences in GenBank (Table 2) which were highly similar to sequences of the Raphidascaris specimens in the present study. Of the sequences listed in Table 2, Zhao et al. (2016) and Li et al. (2016) provided both morphological description and sequence data for $R$. lophii. Raphidascaris lophii along with $R$. trichiuri was considered as junior synonyms of $R$. chirocentri by Sheenko (1992). However, this was later contradicted by Moravec and Justine (2020a) who considered R. lophii and R. trichiuri as valid species. Based on the high level of similarity in the ITS sequences of the specimens in the present study with those available in GenBank we consider the identity of these nematodes as $R$. lophii. This study is the first record of $R$. lophii in New Caledonian waters. It is noteworthy that from the three hosts that we report R. lophii (Table 1) from, Raphidascaris (Ichthyascaris) nemipteri has been reported in Nemipterus furcosus (Valenciennes) (Moravec and Justine 2005), and Raphidascaris (Ichthyascaris) nudicauda has been reported in Saurida undosquamis (Richardson) (Moravec and Justine 2020a). These reports are based on morphology only. We did not have a male specimen in our study to provide comparable morphological description with those reported by Moravec and Justine (2020a).

Another adult specimen found in the present study was a female Cucullanus sp. found in Epinephelus cyanopodus (Richardson). The only other Cucullanus species reported in groupers 
(serranid fish) in the New Caledonian waters have been Cucullanus epinepheli, described from male specimens only, from Epinephelus chlorostigma (Valenciennes) (Moravec and Justine 2017) and C. petterae from Epinephelus merra described from one male and one nongravid female (Moravec and Justine 2020c). Therefore, comparable morphological information is not available. Although comparison of the morphometrics between the nongravid female of $C$. petterae and the single female specimen found in the present study does not suggest the difference is significant, we observed in our specimen cranial surface is more rounded, intestine is wider than the posterior end of the oesophagus and tail is broader.

Of larvae found in this study, Hysterothylacium larval type VI of Shamsi et al. (2013) was one of the most abundant parasites. The main distinguishing feature of larval type VI from other congeneric larval types is the slightly bulbous rounded tail tip decorated with a single minute spine (Shamsi et al. 2013). The hosts for this larval type in the present study were: Chaetodon auriga Forsskål (threadfin butterflyfish), Cheilinus fasciatus (Bloch)(red-breasted wrasse), Gymnocranius grandoculis (Valenciennes) (blue-lined large-eye bream), Moolgarda seheli (Forsskål) (bluespot mullet), Nemipterus furcosus (Valenciennes) (fork-tailed threadfin bream), Parupeneus heptacanthus (Lacepède) (cinnabar goatfish) and Saurida undosquamis (Richardson) (brushtooth lizardfish). Hysterothylacium larval type VI has been reported from New Caledonia previously (Shamsi et al. 2015) from hosts Gymnocranius euanus (Günther) (Japanese large-eye bream), Gymnocranius superciliosus Borsa, Béarez, Paijo \& Chen (eyebrowed large-eye bream), Rastrelliger kanagurta (Cuvier) (Indian mackerel) and Sphyraena forsteri (Cuvier) (bigeye barracuda). None of these host records match the present study. Therefore, the present study is a new host record for seven host species. Hysterothylacium larval type VI has also been found in Australian waters in Chaetodon auriga Forsskål (Shamsi et al. 2013) and also other fish species in Queensland waters (Shamsi et al. 2018b). However, the present study is the first report of Hysterothylacium larval type VI from 
C. auriga Forsskål from New Caledonia. Apart from Hysterothylacium larval type reported in Lizard Island (Table 1) in which the ITS sequences were identical, Hysterothylacium larval type VI in the present study had considerably different ITS-1 and ITS-2 sequences from those previously reported from New Caledonia, Australia and elsewhere. The specific identity of this larval type remains unknown until a comparable sequence data from a well described male nematode becomes available.

Another Hysterothylacium larval type found in the present study was Hysterothylacium larval type XIV. This larval type was first reported in 2015, from New Caledonian waters from hosts Herklotsichthys quadrimaculatus (Rüppell) (bluestripe herring), Rastrelliger kanagurta (Cuvier) (Indian mackerel) and Trichiurus lepturus Linnaeus (largehead hairtail) (Shamsi et al. 2015). The key feature that distinguishes larval type XIV from other Hysterothylacium larval types is the tail ornamentation. Type XIV possesses a tail tip that is bent dorsally (Figure $2 \mathrm{~d}$ ) and is decorated with three to four minute conical spines (Shamsi et al. 2015). The specimens of the present study all had this distinguishing feature and measurements that fall within given ranges (Shamsi et al. 2015). The hosts for this larval type in the present study are new host records. Molecular analysis of specimens in this larval type revealed ITS sequences identical to those previously reported from different developmental stages and other parts of the world suggesting their identity as Hysterothylacium persicum (Table 1).

Nematodes reported in the present study are not of zoonotic significance. However, some of the fish species studied in the present study are known to harbour zoonotic nematodes. For example, Anisakis larval type I has been reported from Nemipterus furcosus (Valenciennes) and Saurida undosquamis (Richardson) in New Caledonian waters (Shamsi et al. 2015; Shamsi et al. 2018a). Nematode species reported in the present study may represent only a small sample of the diversity expected in the highly biodiverse range of hosts and parasite taxa in New Caledonian waters (Justine et al. 2010a; Justine et al. 2010b; Justine et al. 2012a). Completion 
of molecular works on remaining groups in the future will shed further light on their specific identity and taxonomic status. Scanning electron microscopy where enough specimens in good quality are available would also assist in detecting more minute taxonomic details that are difficult to discriminate under a light microscope.

\section{Acknowledgements}

Many students and visiting colleagues were involved in the parasitological survey; they are listed in Justine et al., 2010a, b, 2012b. Valérie Allain (CPS, Nouméa) kindly provided a fish stomach.

\section{Conflict of Interest}

The authors declare that they have no conflict of interest. 


\section{References}

Chen H-X, Zhang L-P, Gibson DI, Lü L, Xu Z, Li H-T, Ju H-D, Li L (2018) Detection of ascaridoid nematode parasites in the important marine food-fish Conger myriaster (Brevoort)(Anguilliformes: Congridae) from the Zhoushan Fishery, China. Parasite Vector 11(1):274

Damin L, Heqing H (2001) Heliconema minnanesis n. sp. (Physalopteridae) and Raphidascaris trichiuri (Yin and Zhang) n. comb. (Ascaridoidea: Anisakidae) in marine fishes. J Parasitol 87(5):1090 - 1094

Ghadam M, Banaii M, Mohammed ET, Suthar J, Shamsi S (2018) Morphological and molecular characterization of selected species of Hysterothylacium (Nematoda: Raphidascarididae) from marine fish in Iraqi waters. J Helminthol 92(1):116-124 doi:10.1017/S0022149X17000128

Hossen MS, Shamsi S (2019) Zoonotic nematode parasites infecting selected edible fish in New South Wales, Australia. Int J Food Microbiol doi:https://doi.org/10.1016/j.ijfoodmicro.2019.108306

Jabbar A, Asnoussi A, Norbury LJ, Eisenbarth A, Shamsi S, Gasser RB, Lopata AL, Beveridge I (2012) Larval anisakid nematodes in teleost fishes from Lizard Island, northern Great Barrier Reef, Australia. Mar Freshwater Res 63(12):1283-1299 doi:10.1071/MF12211

Justine JL (2010) Parasites of coral reef fish: how much do we know? With a bibliography of fish parasites in New Caledonia. Belgian Journal of Zoology 140 (Suppl.):155-190

Justine JL, Beveridge I, Boxshall GA, Bray RA, Moravec F, Trilles JP, Whittington ID (2010a) An annotated list of parasites (Isopoda, Copepoda, Monogenea, Digenea, Cestoda and Nematoda) collected in groupers (Serranidae, Epinephelinae) in New Caledonia emphasizes parasite biodiversity in coral reef fish. Folia Parasitologica (Praha) 57(4):237-262

Justine JL, Beveridge I, Boxshall GA, Bray RA, Moravec F, Whittington ID (2010b) An annotated list of fish parasites (Copepoda, Monogenea, Digenea, Cestoda and Nematoda) collected from Emperors and Emperor Bream (Lethrinidae) in New Caledonia further highlights parasite biodiversity estimates on coral reef fish. Zootaxa(2691):1-40 
Justine JL, Beveridge I, Boxshall GA, Bray RA, Miller TL, Moravec F, Trilles JP, Whittington ID (2012a) An annotated list of fish parasites (Isopoda, Copepoda, Monogenea, Digenea, Cestoda, Nematoda) collected from Snappers and Bream (Lutjanidae, Nemipteridae, Caesionidae) in New Caledonia confirms high parasite biodiversity on coral reef fish. Aquatic Biosystems 8(1) doi:10.1186/2046-9063-8-22

Justine JL, Briand MJ, Bray RA (2012b) A quick and simple method, usable in the field, for collecting parasites in suitable condition for both morphological and molecular studies. Parasitol Res 111(1):341-351 doi:10.1007/s00436-012-2845-6

Kim W-S, Jeon C-H, Kim J-H, Kim D-H, Oh M-J (2012) Current status of anisakid nematode larvae infection in marine fishes caught from the coastal area of Korea between 2010 and 2012. J Fish Pathol 25(3):189-197

Li L, Liu YY, Liu BC, Zhang LP (2012) Morphological and molecular evidence for a new species of the genus Raphidascaris (Nematoda: Anisakidae) from marine fishes from the South China Sea. Parasitol Res 110(4):1473-1479 doi:10.1007/s00436-011-2650-7

Li L, Zhao WT, Guo YN, Zhang LP (2016) Nematode parasites infecting in the starry batfish Halieutaea stellata (Vahl) (Lophiiformes: Ogcocephalidae) from the East and South China Sea. J Fish Dis 39(5):515-529 doi:10.1111/jfd.12374

Li L, Zhao J-Y, Chen H-X, Ju H-D, An M, Xu Z, Zhang L-P (2017) Survey for the presence of ascaridoid larvae in the cinnamon flounder Pseudorhombus cinnamoneus (Temminck \& Schlegel) (Pleuronectiformes: Paralichthyidae). Int J Food Microbiol 241:108-116 doi:10.1016/j.ijfoodmicro.2016.10.018

Moravec F, Justine JL (2005) Two Anisakid Nematodes from Marine Fishes off New Caledonia, Including Raphidascaris (Ichthyascaris) nemipteri n. sp. from Nemipterus furcosus. Syst Parasitol 62(2):101-110 doi:10.1007/s11230-005-5484-9

Moravec F, Justine JL (2017) Two new species of nematode parasites, Cucullanus epinepheli sp. n. (Cucullanidae) and Procamallanus (Spirocamallanus) sinespinis sp. $\mathrm{n}$. (Camallanidae), from marine serranid and haemulid fishes off New Caledonia. Folia Parasitol 64:10 doi:10.14411/fp.2017.011

Moravec F, Justine JL (2018a) Rasheedia n. nom. (Nematoda, Physalopteridae) for Bulbocephalus Rasheed, 1966 (a homonym of Bulbocephalus Watson, 1916), with 
description of Rasheedia heptacanthi $\mathrm{n}$. $\mathrm{sp}$ and $R$. novaecaledoniensis $\mathrm{n}$. $\mathrm{sp}$ from perciform fishes off New Caledonia. Parasite 25:14 doi:10.1051/parasite/2018033

Moravec F, Justine JL (2018b) Three new species of Cucullanus (Nematoda: Cucullanidae) from marine fishes off New Caledonia, with a key to species of Cucullanus from Anguilliformes. Parasite 25 doi:10.1051/parasite/2018050

Moravec F, Justine JL (2019a) Dichelyne (Cucullanellus) bodiani n. sp. and Cucullanus hansoni Olsen, 1952 (Nematoda: Cucullanidae) from fishes off New Caledonia. Syst Parasitol 96(3):299-310 doi:10.1007/s11230-019-09850-2

Moravec F, Justine JL (2019b) New species and new records of camallanid nematodes (Nematoda, Camallanidae) from marine fishes and sea snakes in New Caledonia. Parasite 26:66

Moravec F, Justine JL (2020a) New records of anisakid nematodes from marine fishes off New Caledonia, with descriptions of five new species of Raphidascaris (Ichthyascaris) (Nematoda, Anisakidae). Parasite 27:20

Moravec F, Justine JL (2020b) Paracapillaria (Paracapillaria) gastrica n. sp. (Nematoda: Capillariidae) from the marine fish Synodus variegatus Lacepede (Synodontidae, Aulopiformes) off New Caledonia. Syst Parasitol 97(2):157-163 doi:10.1007/s11230020-09907-7

Moravec F, Justine JL (2020c) New records of cucullanid nematodes from marine fishes off New Caledonia, with descriptions of five new species of Cucullanus (Nematoda, Cucullanidae). Parasite; doiorg/101051/parasite/2020030

Shamsi S, Gasser R, Beveridge I (2013) Description and genetic characterisation of Hysterothylacium (Nematoda: Raphidascarididae) larvae parasitic in Australian marine fishes. Parasitol Int 62:320-328 doi:http://dx.doi.org/10.1016/j.parint.2012.10.001

Shamsi S, Poupa A, Justine JL (2015) Characterisation of Ascaridoid larvae from marine fish off New Caledonia, with description of new Hysterothylacium larval types XIII and XIV. Parasitol Int 64(5):397-404 doi:http://dx.doi.org/10.1016/j.parint.2015.05.014

Shamsi S, Ghadam M, Suthar J, Ebrahimzadeh Mousavi H, Soltani M, Mirzargar S (2016) Occurrence of ascaridoid nematodes in selected edible fish from the Persian Gulf and description of Hysterothylacium larval type XV and Hysterothylacium persicum n. sp. 
(Nematoda: Raphidascarididae). Int $\mathrm{J}$ Food Microbiol 236:65-73 doi:http://dx.doi.org/10.1016/j.ijfoodmicro.2016.07.006

Shamsi S (2017) Morphometric and molecular descriptions of three new species of Hysterothylacium (Nematoda: Raphidascarididae) from Australian marine fish. J Helminthol 91(5):613-624 doi:10.1017/S0022149X16000596

Shamsi S, Briand MJ, Justine J-L (2017) Occurrence of Anisakis (Nematoda: Anisakidae) larvae in unusual hosts in Southern hemisphere. Parasitol Int 66(6):837-840 doi:https://doi.org/10.1016/j.parint.2017.08.002

Shamsi S, Chen Y, Poupa A, Ghadam M, Justine JL (2018a) Occurrence of anisakid parasites in marine fishes and whales off New Caledonia. Parasitol Res:3195-3204 doi:10.1007/s00436-018-6018-0

Shamsi S, Steller E, Chen Y (2018b) New and known zoonotic nematode larvae within selected fish species from Queensland waters in Australia. Int J Food Microbiol 272:73-82 doi:10.1016/j.ijfoodmicro.2018.03.007

Sheenko PS (1992) To the revision of genera Raphidascaris, Raphidascaroides, Ichthyascaris, Alibagascaris (Nematoda: Anisakidae). Biologicheskie Nauki 346:45-55 (In Russian)

Zhang K, Xu Z, Chen H-X, Guo N, Li L (2018) Anisakid and raphidascaridid nematodes (Ascaridoidea) infection in the important marine food-fish Lophius litulon (Jordan) (Lophiiformes: Lophiidae). Int J Food Microbiol 284:105-111 doi:10.1016/j.ijfoodmicro.2018.08.002

Zhao W-T, Lu L, Chen H-X, Yang Y, Zhang L-P, Li L (2016) Ascaridoid parasites infecting in the frequently consumed marine fishes in the coastal area of China: A preliminary investigation. Parasitol Int 65(2):87-98 doi:10.1016/j.parint.2015.11.002 
Table 1- Comparison of the sequences generated in the present study and the associated identification, with identical sequences in GenBank. This table includes information only for those specimens for which ITS sequences were successfully obtained.

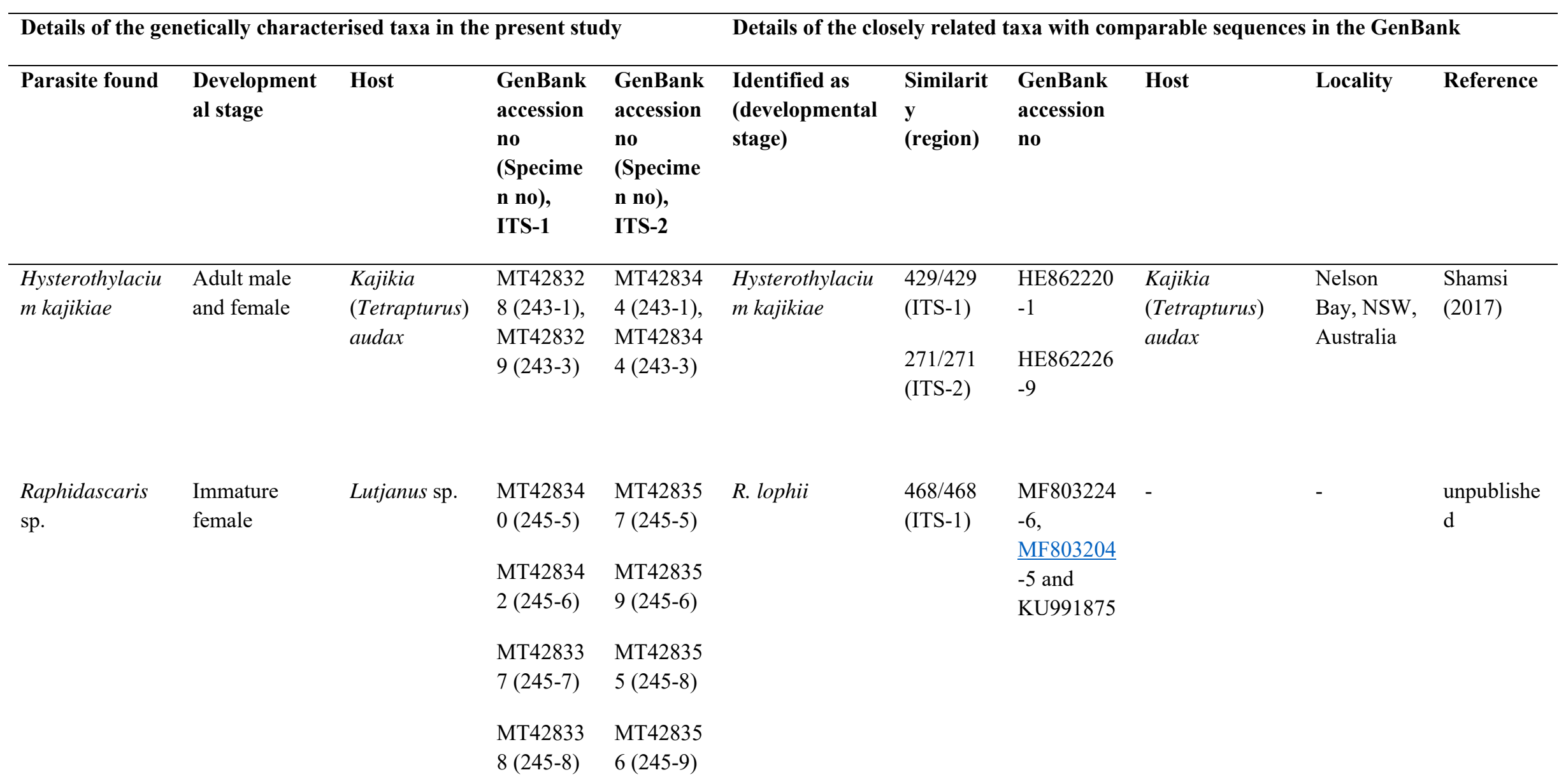




\begin{tabular}{|c|c|c|c|c|c|c|c|c|c|c|}
\hline & & & $\begin{array}{l}\text { MT42833 } \\
9(245-9) \\
\text { MT42834 } \\
1(245- \\
10)\end{array}$ & $\begin{array}{l}\text { MT42835 } \\
8(245- \\
10)\end{array}$ & & & & & & \\
\hline $\begin{array}{l}\text { Raphidascaris } \\
\text { sp. }\end{array}$ & $\begin{array}{l}\text { Adult male } \\
\text { and female }\end{array}$ & $\begin{array}{l}\text { Nemipterus } \\
\text { furcosus }\end{array}$ & $\begin{array}{l}\text { MT42834 } \\
3 \text { (212-2) } \\
\text { (male) } \\
212-1 \\
\text { (female) }\end{array}$ & $\begin{array}{l}\text { MT42836 } \\
1(212-1) \\
\text { (female) } \\
212-2 \\
\text { (male) }\end{array}$ & R. lophii & $\begin{array}{l}468 / 468 \\
\text { (ITS-1) }\end{array}$ & $\begin{array}{l}\text { MF803224 } \\
-6, \\
\text { MF803204 } \\
-5 \text { and } \\
\text { KU991875 }\end{array}$ & - & - & $\begin{array}{l}\text { unpublishe } \\
\text { d }\end{array}$ \\
\hline $\begin{array}{l}\text { Raphidascaris } \\
\text { sp. }\end{array}$ & L3 & $\begin{array}{l}\text { Saurida } \\
\text { undosquamis }\end{array}$ & $197-6$ & $\begin{array}{l}\text { MT42836 } \\
0(197-6)\end{array}$ & R. lophii & $\begin{array}{l}468 / 468 \\
\text { (ITS-1) }\end{array}$ & $\begin{array}{l}\text { MF803224 } \\
-6, \\
\text { MF803204 } \\
-5 \text { and } \\
\text { KU991875 }\end{array}$ & - & - & $\begin{array}{l}\text { unpublishe } \\
\text { d }\end{array}$ \\
\hline $\begin{array}{l}\text { Hysterothylaciu } \\
\text { m larval type VI }\end{array}$ & L3 & $\begin{array}{l}\text { Gymnocraniu } \\
\text { s grandoculis }\end{array}$ & - & $\begin{array}{l}\text { MT42834 } \\
6(280-1)\end{array}$ & $\begin{array}{l}\text { Hysterothylaciu } \\
m \text { sp. type VA }\end{array}$ & $\begin{array}{l}262 / 262 \\
\text { (ITS-2) }\end{array}$ & JX848691 & Unknown * & $\begin{array}{l}\text { Lizard Is., } \\
\text { Queenslan } \\
\text { d, Australia }\end{array}$ & $\begin{array}{l}\text { Jabbar et } \\
\text { al. (2012) }\end{array}$ \\
\hline \multirow[t]{2}{*}{$\begin{array}{l}\text { Hysterothylaciu } \\
\text { m larval type } \\
\text { XIV }\end{array}$} & L3 & $\begin{array}{l}\text { Saurida } \\
\text { undosquamis } \\
\text { Nemipterus } \\
\text { furcosus }\end{array}$ & $\begin{array}{l}\text { MT42833 } \\
0(216-8) \\
\text { MT42833 } \\
1(197-2)\end{array}$ & $\begin{array}{l}\text { MT42834 } \\
7(216-8) \\
\text { MT42834 } \\
8(197-2)\end{array}$ & \multirow[t]{2}{*}{$\begin{array}{l}\text { Hysterothylaciu } \\
\text { m larval type } \\
\text { XIV }\end{array}$} & \multirow[t]{2}{*}{$\begin{array}{l}436 / 436 \\
(\text { ITS-1); } \\
276 / 276 \\
\text { (ITS-2) }\end{array}$} & $\begin{array}{l}\text { MK161424 } \\
\text { MK161449 }\end{array}$ & \multirow[t]{2}{*}{$\begin{array}{l}\text { Engraulis } \\
\text { australis }\end{array}$} & \multirow[t]{2}{*}{$\begin{array}{l}\text { NSW, } \\
\text { Australia }\end{array}$} & \multirow[t]{2}{*}{$\begin{array}{l}\text { (Hossen \& } \\
\text { Shamsi, } \\
\text { 2019) }\end{array}$} \\
\hline & & & $\begin{array}{l}\text { MT42833 } \\
2(197-4)\end{array}$ & $\begin{array}{l}\text { MT42834 } \\
9(197-4)\end{array}$ & & & & & & \\
\hline
\end{tabular}




$\begin{array}{ll}\text { MT42833 } & \text { MT42835 } \\ 3 \text { (197-5) } & 0(197-5) \\ \text { MT42833 } & \text { MT42835 } \\ 4(197-8) & 1(197-8) \\ \text { MT42833 } & \text { MT42835 } \\ 5 \text { (256-6) } & 2(256-6) \\ & \\ \text { MT42833 } & \text { MT42835 } \\ 6(197-9) & 3(197-9)\end{array}$

\begin{tabular}{|c|c|c|c|c|c|}
\hline $\begin{array}{l}\text { Hysterothylaciu } \\
\text { m persicum }\end{array}$ & $\begin{array}{l}436 / 436 \\
(\text { ITS-1); } \\
276 / 276 \\
(\text { ITS-2) }\end{array}$ & $\begin{array}{l}\text { LT576366- } \\
8 ; \\
\text { LT576370- } \\
1\end{array}$ & $\begin{array}{l}\text { Scomberomorus } \\
\text { commerson }\end{array}$ & $\begin{array}{l}\text { Persian } \\
\text { Gulf, Iran }\end{array}$ & $\begin{array}{l}\text { Shamsi et } \\
\text { al. (2016) }\end{array}$ \\
\hline $\begin{array}{l}\text { Hysterothylaciu } \\
m \text { larval type } \mathrm{X}^{\#}\end{array}$ & $\begin{array}{l}276 / 276 \\
(\text { ITS-2) }\end{array}$ & JX848679 & Unknown $^{\wedge}$ & $\begin{array}{l}\text { Lizard Is., } \\
\text { Queenslan } \\
\text { d, Australia }\end{array}$ & $\begin{array}{l}\text { Jabbar et } \\
\text { al. }(2012)\end{array}$ \\
\hline $\begin{array}{l}\text { Hysterothylaciu } \\
\text { m larval type } \\
\text { XIV }\end{array}$ & $\begin{array}{l}436 / 436 \\
(\text { ITS-1); } \\
276 / 276 \\
(\text { ITS-2) }\end{array}$ & $\begin{array}{l}\text { MG594310 } \\
-12 ; \\
\text { MG594333 }\end{array}$ & $\begin{array}{l}\text { Tripodichthys } \\
\text { angustifrons }\end{array}$ & $\begin{array}{l}\text { Green Is., } \\
\text { Moreton } \\
\text { Bay, } \\
\text { Queenslan } \\
\text { d, Australia }\end{array}$ & $\begin{array}{l}\text { Shamsi et } \\
\text { al. (2018b) }\end{array}$ \\
\hline $\begin{array}{l}\text { Hysterothylaciu } \\
\text { m larval type } \\
\text { XIV }\end{array}$ & $\begin{array}{l}276 / 276, \\
\text { and } \\
275 / 276 \\
\text { (ITS-2) }\end{array}$ & $\begin{array}{l}\text { LN651105 } \\
-7\end{array}$ & $\begin{array}{l}\text { Herklotsichthys } \\
\text { quadrimaculatu } \\
\text { s, Rastrelliger } \\
\text { kanagurta, }\end{array}$ & $\begin{array}{l}\text { New } \\
\text { Caledonia }\end{array}$ & $\begin{array}{l}\text { Shamsi et } \\
\text { al. (2015) }\end{array}$ \\
\hline
\end{tabular}


* The authors listed A. polyacanthus, C. citrinellus, S. commerson, S. apicalis as host for all what they labelled as type V. However only one sequence is available in the GenBank and it is not known which one of them is the host for the parasite. For issues relate with their identification see the Discussion.

\# Erroneous identification.

${ }^{\wedge}$ The authors listed A. endrachtensis, C. cyanostigma, Hyporhamphus affinis as host for all what they labelled as type x. However only one sequence is available in the GenBank and it is not known which one of them is the host for the parasite. For issues relate with their identification see the Discussion. 
Table 2- Comparison of the ITS-1 and ITS-2 sequences of the Raphidascaris specimens in the present study with the highly similar sequences in the in the GenBank

\begin{tabular}{|c|c|c|c|c|c|}
\hline $\begin{array}{l}\text { Identified as (developmental } \\
\text { stage) }\end{array}$ & Similarity (region) & GenBank accession no & Host & Locality & Reference \\
\hline R. lophii (not mentioned) & $466 / 468$ (ITS-1) & $\begin{array}{l}\text { MF422212 and } \\
\text { KX110077 }\end{array}$ & - & - & Unpublished \\
\hline R. lophii (L3) & $\begin{array}{l}\text { 466/468 (ITS-1); } \\
\text { 286/287 (ITS-2) }\end{array}$ & $\underline{\mathrm{MH} 211575-84}$ & Lophius litulon & East China Sea & Zhang et al. (2018) \\
\hline Raphidascaris (larval type) & 287/287 (ITS-2) & $\underline{\text { LN651108-9 }}$ & $\begin{array}{l}\text { Branchiostegus wardi, Carangoides } \\
\text { chrysophrys, Chirocentrus dorab and } \\
\text { Diodon hystrix }\end{array}$ & New Caledonia & Shamsi et al. (2015) \\
\hline R. trichurii ${ }^{*}$ (not mentioned) & 287/287 (ITS-2) & FJ009682 & Muraenesox cinereus & $\begin{array}{l}\text { Taiwan Strait, Fujian, } \\
\text { China }\end{array}$ & Damin and Heqing (2001) \\
\hline R. lophii (L3) & $\begin{array}{l}\text { 466/468 (ITS-1); } \\
\text { 286/287 (ITS-2) }\end{array}$ & $\underline{\text { MF539818-20 }}$ & $\begin{array}{l}\text { Conger } \\
\text { myriaster }\end{array}$ & South China Sea & Chen et al. (2018) \\
\hline R. lophii (L3) & 286/287 (ITS-2) & KX110077 & Pseudorhombus cinnamoneus & Yellow Sea, China & Li et al. (2017) \\
\hline R. lophii (female and L3) & 286/287 (ITS-2) & $\frac{\mathrm{KP} 419720}{31 \text { and } \underline{\mathrm{KP}} 326533-8}$ & $\begin{array}{l}\text { Uroconger lepturus } \\
\text { Scomberomorus niphonius }\end{array}$ & South China Sea & Zhao et al. (2016), \\
\hline
\end{tabular}


Scomber japonicas

Mene maculate

Pterois russelii

Lepidotrigla japonica

Rhynchoconger ectenurus

R. lophii (male)

R. lophii (larvae)

R. lophii (-)
285/287 (ITS-2)

286/287 (ITS-2)

285/287 (ITS-2) $\underline{\text { KP326532 }}$

$\underline{\text { JX974559 }}$

$\underline{\text { JF809816 }}$
South China Sea

Jeju, South Korea
Zhao et al. (2016)

Kim et al. (2012)

Li et al. (2012)

* There is no mention of the GenBank accession number in the paper, hence it is not known whether it was obtained from a male, female or larva.

As a result identification as $R$. trichurii is dubious. 

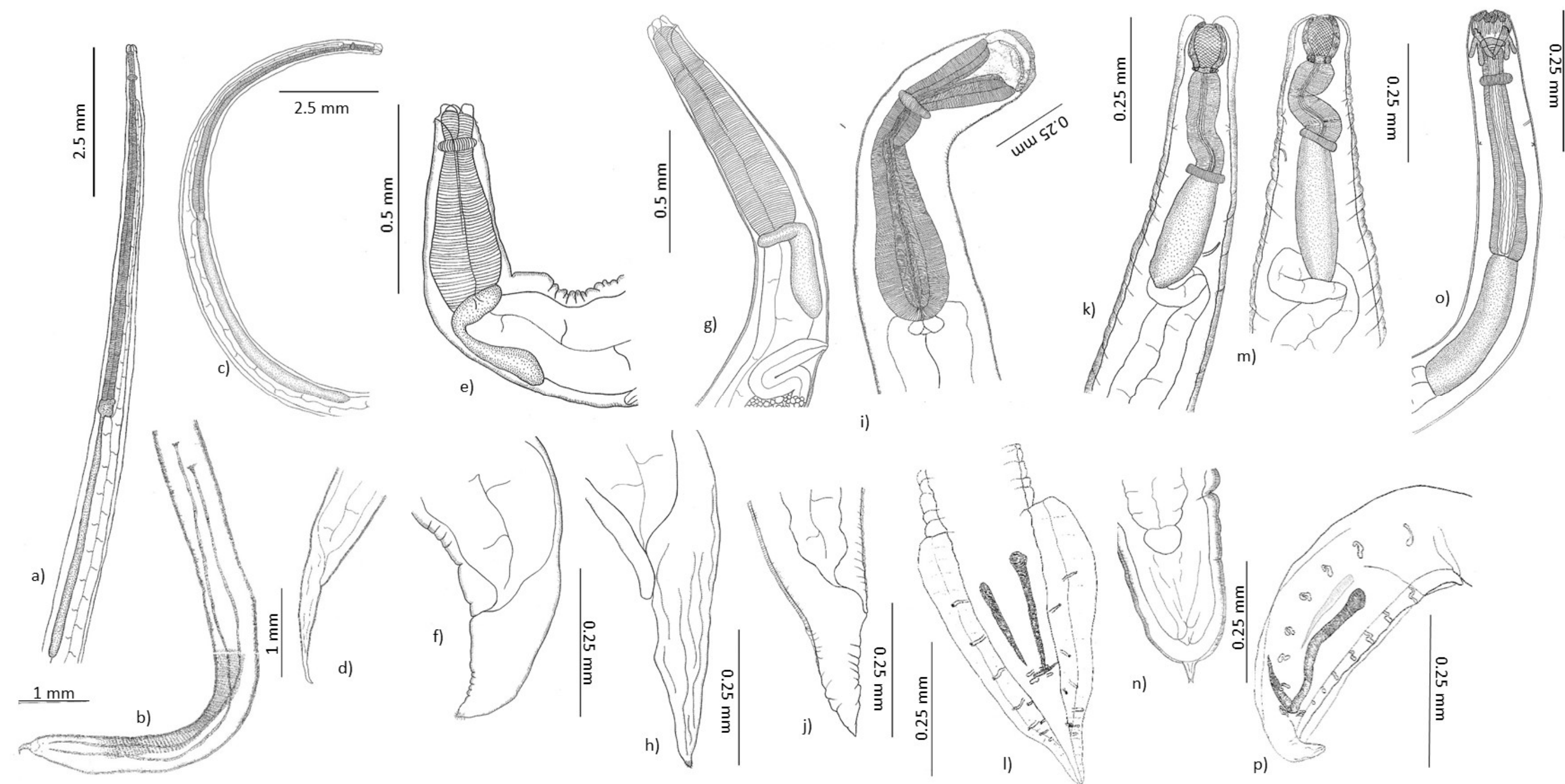

Figure 1) Adult nematodes found in the present study; a to d) Hysterothylacium kajikiae from Kajikia (Tetrapturus) audax, a \& b) anterior and posterior ends 
of male \#243-6, c \& d) anterior and posterior ends of female \#244-3; e \& f) anterior and posterior ends of an immature female Raphidascaris sp. from Lutjanus sp. specimen number \#245-5; g \& h) anterior and posterior ends of a mature female Raphidascaris sp. from Nemipterus furcosus, specimen number \#212-1; i \& j) Cucullanus sp. female from Epinephelus cyanopodus, specimen number \#282-3, i) anterior end lateral view and j) posterior end; $k$ \& 1) anterior and posterior ends of Procamallanus (Spirocamallanus) monotaxis male from Lethrinus genivittatus, specimen number \#200-7; $\mathrm{m} \& \mathrm{n}$ ) anterior and posterior ends of Procamallanus (Spirocamallanus) monotaxis female from Lethrinus genivittatus, specimen number \#200-1; o \& p) Camallanus carangis male from Parupeneus heptacanthus, specimen number 231-19 o) anterior end, p) posterior end dorso-lateral view; q, r, s) Rhabdochonidae gen. sp., q) anterior end of a female (lateral view), specimen numbers \#234-9, r) posterior end of a male (lateral view), specimen numbers \#237-5, s) posterior of a female (lateral view), specimen number \#234-9. 


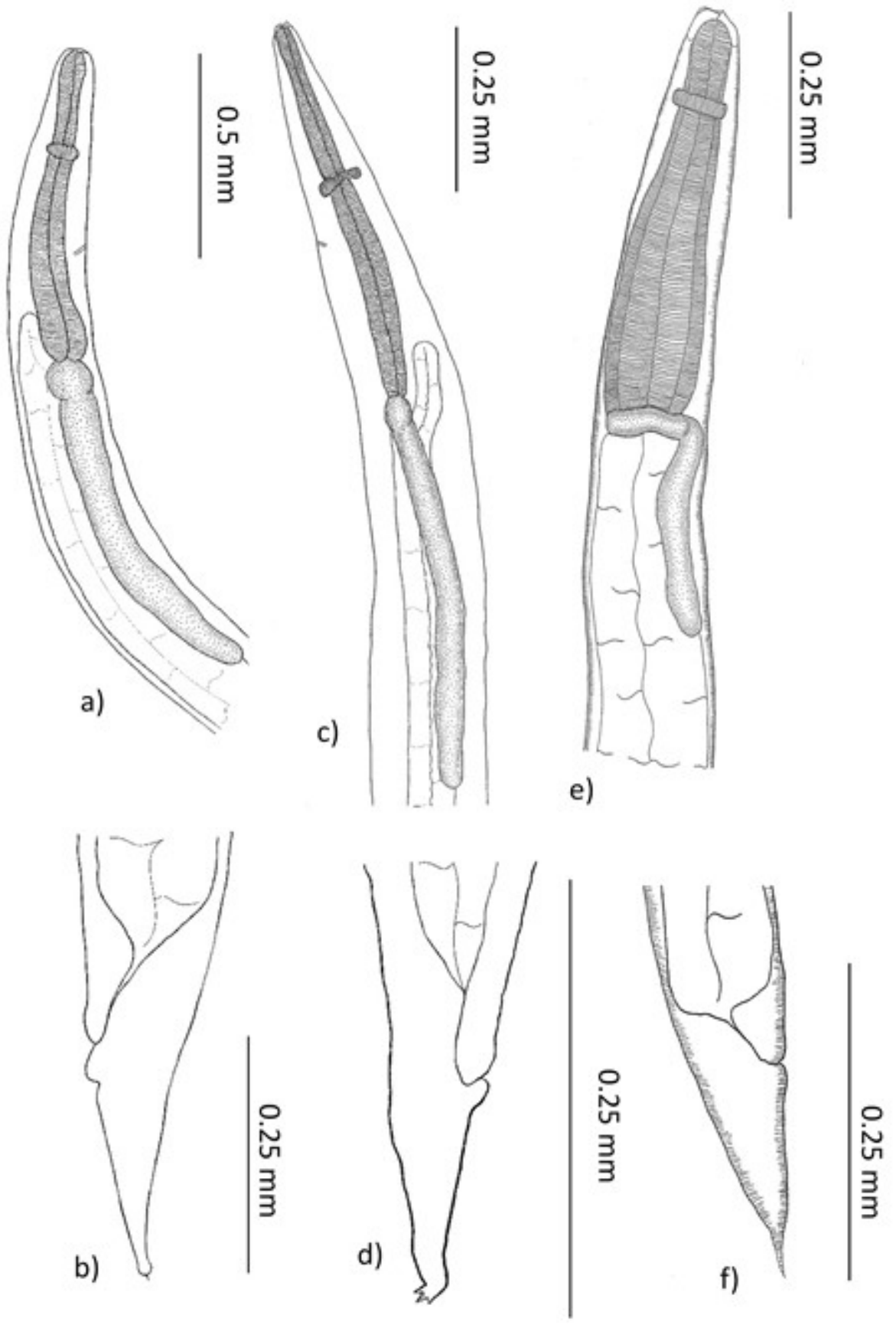

Figure 2) a \& b) anterior and posterior ends of Hysterothylacium larval type VI of Shamsi et al. (2013) from Nemipterus furcosus, specimen number \#222-6; c \& d) anterior and posterior ends of Hysterothylacium larval type XIV of Shamsi et al. (2015), from Saurida undosquamis, specimen number \#197-4; e \& f) Raphidascaris larval type from Parupeneus heptacanthus, specimen number \#229-2. 